\title{
PERBEDAAN EFEKTIFITAS FILM ANIMASI DAN FILM CERITA TERHADAP PENINGKATANPENGETAHUAN DAN SIKAP ANAK TENTANG KESEHATAN GIGI
}

\section{THE DIFFERENCE OF EFFECTIVENESS OF ANIMATED AND NON-ANIMATED MOVIES ON THE IMPROVEMENT OF CHILDREN'S KNOWLEDGE AND ATTITUDES ABOUT DENTAL HEALTH}

\author{
Isha Winda Sandya ${ }^{1}$, Sri Widati ${ }^{1}$ \\ ${ }^{1}$ Departemen Promosi Kesehatan dan Ilmu Perilaku, \\ Fakultas Kesehatan Masyarakat, Universitas Airlangga, Surabaya, Indonesia \\ Alamat Korespondensi: Isha Winda Sandya \\ Email : Isha.sandya17@gmail.com
}

\begin{abstract}
According to Basic Health Research 2013, 28.9\% of the age group of less than 12 years old, i.e. age 5-9 years old, suffered dental caries. The aim of this study was to analyze the effectiveness of animated movies and nonanimated movies in improving children's knowledge and behavior concerning dental health. This study was designed based on quasi experimental design. The samples of this study were the students of Class $3 A$ and Class $3 B$ of SDN 03 Kepanjen consisting of 63 students. The independent variables of this study were animated and nonanimated movies concerning dental health, whereas the dependent variables were children's knowledge and attitudes. The collected data were analyzed using Mann Whitney test. The findings of this study showed that the respondents were aged between 8 and 10 years old, and there was no difference in terms of students' knowledge before and after they received intervention through animated and non-animated movies. Animated movie seemed to be more effective in improving the respondents' knowledge to maintain dental health than non-animated movie as indicated by the average score for animated movie intervention which was higher than non-animated movie intervention.
\end{abstract}

Keywords: animated movie, non-animated movie, dental health, knowledge

\begin{abstract}
ABSTRAK
Berdasarkan Riset Kesehatan Dasar tahun 2013 menyatakan bahwa kelompok umur kurang dari 12 tahun yaitu umur 5-9 tahun 28,9\% menderita karies gigi. Tujuan dari penelitian ini adalah menganalisis efektivitas metode film animasi dan film cerita terhadap peningkatan pengetahuan dan sikap anak tentang kesehatan gigi. Jenis penelitian ini adalah penelitian eksperimental semu. Sampel dalam penelitian ini adalah siswa kelas 3A dan 3B SDN 03 Kepanjen Kab. Malang, berjumlah 63 siswa. Variabel bebas dalam penelitian ini adalah film animasi dan film cerita tentang kesehatan gigi, sedangkan variabel terikatnya adalah pengetahuan dan sikap. Data yang diperoleh dianalisis menggunakan uji statistik Mann Whitney test. Hasil penelitian menunjukan bahwa responden berusia 8-10 tahun. Ada perbedaan pengetahuan responden sebelum dan sesudah diberikan intervensi berupa pemutaran film. Film animasi lebih efektif dari pada film cerita dalam meningkatkan pengetahuan dan sikapresponden dalam menjaga kesehatan gigi, karena dilihat dari hasil rerata kedua kelompok nilai film animasi lebih tinggi.
\end{abstract}

Kata Kunci : film animasi, film cerita, kesehatan gigi, pengetahuan.

\section{PENDAHULUAN}

Kesehatan gigi dan mulut adalah kesehatan yang sangat penting untuk diperhatikan selain kesehatan tubuh secara umum. Kesehatan gigi dan mulut dapat mempengaruhi kesehatan didalam tubuh secara menyeluruh, hal ini dikarenakan gigi dan mulut merupakan bagian tubuh yang sangat integral karena tidak dapat dipisahkan dari kesehatan tubuh secara umum (Malik, 2008)

Perawatan gigi sering dianggap tidak terlalu penting, padahal kesehatan gigi manfaatnya sangatlah vital didalam menunjang penampilan diri (Pratiwi, 2004). Hal ini menjadikan masalahkesehatan gigi yang sering timbul pada anak usia 4 sampai 10 tahun (Fankari, 2004). Penyakit karies gigi pada anak-anak banyak dan sering 
terjadi, namun hal ini kurang mendapat perhatian yang serius dari orang tua. Kemampuan anak dalam menjaga kesehatan gigi dengan baik dan benar merupakan salah satu faktor yang cukup penting untuk pemeliharaan kesehatan gigi dan mulut (Dorothy, 2008).

Menurut data Riskesdas (2013), terjadi peningkatan prevalensi karies gigi di Indonesia, yakni penderita karies gigi aktif meningkat sebesar $9,8 \%$ dari $43,4 \%$ pada tahun 2007 menjadi 53,2\% pada tahun 2013, sedangkan penderita pengalaman karies meningkat $5,1 \%$ dari $67,2 \%$ pada tahun 2007 naik menjadi $72,3 \%$ pada tahun 2013 . Menurut hasil data Riskesdas tahun 2013, Provinsi Jawa Timur memiliki indeks DMFT 5,5. Dari hasil data Profil Kesehatan Jawa Timur didapatkan bahwa Kab. Malang masuk dalam 10 besar kabupaten yang memiliki masalah gigi dan mulut di indonesia.

Pada anak usia sekolah, anak dapat diarahkan ke arah positifyang bisa membantu mereka mendapat perkembangan sikap, pengetahuan, ketrampilan dan daya cipta yang baik. Pendidikan kesehatan sangatlah penting karena bertujuan untuk meletakkan dasar ke arah perkembangan sikap, pengetahuan, ketrampilan dan daya cipta yang diperlukan anak anak dalam menyesuaikan diri mereka dengan lingkungan dan untuk pertumbuhan serta perkembanganya selanjutnya.

Anak Sekolah Dasar pada usia 6 sampai 12 tahun sangat memerlukan perawatan gigi dan mulut yang lebih intensif, karena pada usia ini anak akan mengalami pergantian gigi dan tumbuhnya gigi baru dan pada usia ini semua gigi primer telah lepas atau tanggal dan mayoritas gigi permanen telah tumbuh (Worotitjan, 2013).Anak usia sekolah adalah anak yang memiliki usia antara 6 sampai 12 tahun hal ini dianggap anak mulai bertanggung jawab atas perilakunya terhadap orang tua, teman sebaya, dan orang lain (Wong, 2009).Informasi tentang kesehatan gigi yang baik dan benar yang diperoleh dari kedua orang tua mereka sangatlah berpengaruh terhadap kesehatan gigi dan mulut mereka karena ibu akan mendidik dan mengajarkan anak untuk menggosok gigi dan mengatur pola makananan dana jajanan. Orang tua memiliki peran penting dalam kesehatan anak, yaitu sebagai perawatan secara langsung untuk menyampaikan metode pendidikan kesehatan.

Sekolahmerupakan tempat anakanak untuk belajar, berkreasi, bersosialisasi, dan bermain sehingga pelayanan kesehatan di sekolah pada anak sekolah lebih efektif. Anak dalam masa pertumbuhan, memerlukan upaya perawatan kesehatan sekolah dengan memaksimalkan melalui usaha kesehatan di sekolah (UKS) (Efendi \&Makhudli, 2009).

Sikap adalah perasaan, pikiran dan kecenderungan seseorang untuk bertindak atau seseorang akan melakukan sesuatu perbuatan apabila dia memandang atau yakin perbuatan itu positif atau negatif dan bila ia percaya bahwa orang lain ingin agar ia melakukannya. Stimulus -OrganismeRespon (S-O-R)berasal dari bidang psikologi kemudian menjadi teori komunikasi. Mengacu pada teori komunikasi media use and effect dengan media yang diberikan akan memberikan efek terhadap respondennya (Effendy, 2003).

Media terbagimenjadi tiga yaitu media auditif, media visual dan media audio visual. Media auditif adalah media yang hanya mengandalkan kemampuan suara saja, sedangkan media visual mengandalkan indra pengelihatan saja, dan media audio visual adalah media yang mempuayai unsur suara dan unsur gambar (Mubarak, 2007). Para siswa tidak hanya diajar melalui lambang verbal saja yaitu seperti metode ceramah dari guru, tetapi juga dapat diberikan variasi belajar mengajar dengan mengunakan media audio visual contohnya film.Film merupakan sebuah komunikasi antara pengirim pesan dan penerima pesan yang bersifat dapat dilihat dan di dengar, film juga dapat untuk menyampaikan informasi kepada sekelompok orang atau 
masyarakat yang berkumpul di suatu tempt tertentu (Effendy, 2009).

Pesan yang disampaikan dalam film yaitu dengan menggunakan mekanisme lambang atau tanda yang ada pada pikiran manusia berupa isi pesan, suara dan percakapan.Film dikelompokkan menjadi beberapa jenis salah satunya adalah film animasi atau film kartun adalah imajinasi atau karya lukis dari seniman pelukis yang menggunakan gambar bergerak dan karakternya sesuai dengan yang di inginkan, sinematografi yang menimbulkangagasan ide untuk menghidupkan gambar yang mereka fikirkan, lukiskan dan lukisan itu menimbulkan hal yang bersifat lucu dan menarik (Dony K, 2011)

Film cerita adalah film yang mengandung suatu cerita, film yang dibuat atau diproduksi berdasarkan cerita yang dikarang dan mainkan oleh seorang aktor atau aktris. Keberhasilan suatu proses belajar mengakar tidak pernah lepas dari peran media didalamnya, karena hal ini media adalah bagian yang sangat integral dalam proses pendidikan di sekolah. Demikian media sangat diharapkan dapat mengatasi hambatan dalam proses belajar mengajar.

Hasilstudi pendahuluan yang dilakukan dengan mewawancarai guru kelas 3A dan 3B di Sekolah Dasar Negeri 03 Kepanjen Kabupaten Malang, selama tahun ajaran 2016/2017 belum ada penyuluhan tentang gosok gigi terhadap siswa-siswi dengan menggunakan media audio visual. Penyuluhan biasanya dilakukan dilakukan oleh guru olahraga. Berdasarkan survei yang dilakukan secara langsung dengan mengambil kelas 3A dan 3Bdengan mengambil 20 orang siswa-siswi rata-rata memiliki pengetahuan yang cukup. Siswasiswi yang selalu menggosok gigi sebelum tidur sebanyak 8 anak. siswa yang menggosok gigi pada saat mandi pagi hari sebanyak 17 anak dan 11 anak yang mengkonsumsi makanan atau minuman setelah menggosok gigi malam. Anak yang menggosok gigi dengan cara benar sebanyak 16 siswa.
Tujuan dari penelitian ini adalah mengidentifikasi perbedaan efektifitas film animasi dan film cerita terhadap peningkatan pengetahuan dan sikap anak tentang kesehatan gigi diSekolah Dasar Negeri 03 Kepanjen Kab. Malang.

\section{METODE PENELITIAN}

Penelitian ini merupakan penelitian kuantitatif dengan pendekatan cross sectional.Dengan desain penelitian yang digunakan dalam penelitian ini adalah eksperimental semu yang bertujuan untuk mengetahui sebab akibat dalam menjaga kesehatan gigi pada anak kelas 3A dan 3B Sekolah Dasar 03 Kepanjen Kab. Malang. Penelitian dilakukan di Sekolah Dasar Negeri 03 Kepanjen Kab. Malang. Penelitian dilaksanakan sejak bulan November sampai Desember 2017.

Populasi dalam penelitian ini adalahseluruh siswa Sekolah Dasar Negeri 03 Kepanjen Kab. Malang.Sampelpada penelitian iniadalah siswa siswi kelas $3 \mathrm{~A}$ dan 3B. menggunakan teknik purposive samplingatau judgmentalsampling. Pengambilan sampel secara purposif merupakan cara penarikan sampel yang dilakukan memilih subjek berdasarkan kriteria spesifik yang ditetapkan oleh peneliti. Kriteria inklusi dalam penelitian ini adalah siswa yang memiliki usia 8-10 tahun, siswa yang mendapat persetujuan orang tua untuk ikut serta dalam penelitian ini, dan hadir pada saat penelitian. Berdasarkan kriteria yang ada didapatkan responden sebanyak 63 anak. Hasil analisis hanya berlaku pada sampel penelitian ini.

Alat yang digunakan dalam penelitian ini adalah lembar kuesioner yang berisikan karakteristik responden, pengetahuan responden dalam menjaga kesehatan gigi, sikap responden dalam menjaga kesehatan gigi. Film animasi diambil dari youtube milik Ayo Gembira channel dengan durasi 3 menit 3 detik. Film cerita di ambil dari youtube milik Fachreza Hilayani UGM dengan durasi film 2 menit 51 detik. 
Data yang didapat diperiksa kembali sebelum dilakukan editing, kemudian dilakukan pengkodingan, data dimasukkan didalam tabel frekuensi sesuai dengan kategori masing-masing. Kemudian tahap

\section{HASIL}

Data responden yang terkumpul pada penelitian ini adalah siswa siswi kelas $3 \mathrm{~A}$ dan 3BSDN 03 Kepanjen Kab. Malang didapatkan berbagai karakteristik yang dikelompokkan berdasarkan umur, jenis kelamin peneliti gunakan untuk membedakan responden laki - laki dan analisis data, analisis data dikakukan dengan uji Mann Whiiney Test untuk mengetahui perbedaan kelompok

animasi dan kelompok cerita.

Tabel 1.Keadaan distribusi responden menurut usia, jenis kelamin,pendidikan terakhir orang tua di kelas 3A dan 3B SDN 03 Kepanjen 2017

\begin{tabular}{|c|c|c|c|c|}
\hline \multirow[t]{2}{*}{ Umur } & \multicolumn{2}{|c|}{ Animasi } & \multicolumn{2}{|c|}{ Cerita } \\
\hline & $\mathbf{F}$ & $\%$ & $\mathbf{F}$ & $\%$ \\
\hline 8 & 10 & 32,3 & 9 & 28,1 \\
\hline 9 & 21 & 67,7 & 21 & 65,6 \\
\hline 10 & 0 & 0 & 2 & 6,2 \\
\hline Total & 31 & 100 & 32 & 100 \\
\hline Jenis Kelamin & $\mathbf{F}$ & $\%$ & $\mathbf{F}$ & $\%$ \\
\hline Perempuan & 21 & 67,7 & 22 & 68,8 \\
\hline Laki-laki & 10 & 32,3 & 10 & 31,2 \\
\hline Total & 31 & 100 & 32 & 100 \\
\hline $\begin{array}{l}\text { Pendidikan terakhir } \\
\text { Ortu }\end{array}$ & $\mathbf{F}$ & $\%$ & $\mathbf{F}$ & $\%$ \\
\hline SD & 4 & 12,9 & 5 & 15,6 \\
\hline SMP & 2 & 6,5 & 6 & 18,8 \\
\hline SMA & 20 & 64,5 & 16 & 50,0 \\
\hline D3 & 1 & 3,2 & 3 & 9,4 \\
\hline S1 & 4 & 12,9 & 2 & 6,2 \\
\hline Total & 31 & 100 & 32 & 100 \\
\hline
\end{tabular}

Berdasarkan Tabel 1 diatas dapat disimpulkan antara kelompok film animasi dan kelompok film cerita memiliki distribusi usia yang hampir sama. Sebagian besar responden pada kelompok film animasi dan kelompok film cerita memiliki umur9tahun. Sebagian besar responden pada kelompok film animasi dan kelompok film cerita

Keadaan pengetahuan siswa-siswi kelas 3A dan 3B SDN 03 Kepanjen Kab. Malang dapat dikalsifikasikan menjadi 3 kategori, yang terdiri dari kurang, cukup dan perempuan, pendidikan terakhir orang tua dibagi menjadi lima kategori. Umur responden, jenis kelamin responden dan pendidikan terakhir responden secara keseluruhan dapat dilihat pada Tabel 1 di bawah ini. 
Tabel 2.Keadaan pengetahuan sebelum dan sesudah diberikan intervensi

\begin{tabular}{lccccccccc}
\hline Pengetahuan & \multicolumn{3}{c}{ Animasi } & \multicolumn{2}{c}{ Post } & \multicolumn{2}{c}{ Pre } & \multicolumn{2}{c}{ Post } \\
\hline & \multicolumn{2}{c}{ Pre } & \multicolumn{2}{c}{ Porita } \\
Kurang & F & $\%$ & F & $\%$ & F & $\%$ & F & $\%$ \\
Cukup & 3 & 9,7 & & 4 & 12,9 & 12 & 37,5 & 4 & 12,5 \\
Baik & 9 & 29,0 & 4 & 12,9 & 15 & 46,9 & 14 & 43,8 \\
Total & 19 & 61,3 & 23 & 74,2 & 5 & 15,6 & 14 & 43,8 \\
& 31 & 100 & 31 & 100 & 32 & 100 & 32 & 100 \\
\hline
\end{tabular}

Berdasarkan Tabel 2 di atas ini dapat disimpulkan bahwa pada kelompok animasi cendrung mengalami peningkatan pengetahuan. Hasil dari penelitian yang didapatkan dapat dilihat bahwa siswa-siswi memiliki pengetahuan yang baik, sebelum diberikan pendidikan kesehatan dengan media audiovisual berupa film animasi sebanyak 19 siswa $(61,3 \%)$ memiliki pengetahuan yang baik dan cenderung mengalami peningkatan skor pengetahuan menjadi 23 siswa $(74,2 \%)$. Sama halnya pada kelompok film cerita juga cenderung mengalami peningkatan pengetahuan dalam menjaga kesehatan gigi setelah diberikan intervensi pemutaran film tentang menjaga kesehatan gigi Dapat dilihat bahwa siswa-siswi pada kelompok film cerita juga cenderung mengalami peningkatan pengetahuan setelah diberikan intervensi, mula-mula sebelum dilakukan intervensi didapatkan 12 siswa $(12,5 \%)$ memiliki pengetahuan kurang tentang menjaga kesehatan gigi dan cenderung mengalami peningkatan setelah dilakukan intervensi menjadi 14 siswa $(43,8 \%)$ berpengetahuan baik.

Keadaan sikap siswa-siswi kelas 3A dan 3B SDN 03 Kepanjen Kab. Malang dapat dikalsifikasikan menjadi 3 kategori, yang terdiri dari kurang, cukup dan baik. Berdasarkan kriteria pengkategorian yang diadaptasi dari Azwar S, (2011) diperoleh hasil klasifikasi sikap sebagai berikut :

Tabel 3.Keadaan sikap sebelum dan sesudah diberikan intervensi

\begin{tabular}{lcccccccc}
\hline Sikap & \multicolumn{4}{c}{ Animasi } & \multicolumn{4}{c}{ Cerita } \\
& Pre & \multicolumn{3}{c}{ Post } & Pre & Post & \\
& F & \% & F & \% & F & \% & F & \% \\
\hline Kurang & 3 & 9,7 & 2 & 6,5 & - & - & 2 & 6,2 \\
Cukup & 10 & 32,3 & 8 & 25,8 & 15 & 46,9 & 4 & 12,5 \\
Baik & 18 & 58,1 & 21 & 67,7 & 17 & 53,1 & 26 & 81,2 \\
Total & 31 & 100 & 31 & 100 & 32 & 100 & 32 & 100 \\
\hline
\end{tabular}

Berdasarkan Tabel 3 diatas sebelum diberikan pendidikan kesehatan dengan media film animasi mayoritas responden memiliki sikap yang baik dalam menjaga kesehatan gigi 18 siswa $(58,1 \%)$ memiliki sikap yang baik. Setelah dilakukan intervensi berupa pemutaran film animasi tentang menjaga kesehatan gigi sikap responden cenderung mengalami peningkatan yang baik menjadi 21 siswa $(67,7 \%)$. Sedangkan pada kelompok film cerita juga cenderung mengalami peningkatan sikap tentang mejaga kesehatan gigi, sebelum dilakukan intervensi responden sudah memiliki sikap yang baik sebesar 17 siswa $(53,1 \%)$ sesaat setelah dilakukan intervensi cenderung mengalami peningkatan menjadi 26 siswa $(81,2 \%)$.

Rerata pengetahuan dan sikap responden mengenai pentingnya menjaga kesehatan gigi pada kelompok film animasi dan kelompok film cerita sesudah diberikan 
intervensi. Media dikatakan efektif dengan menggunakan nilai rata - rata kriteria tersebut dirujuk dari penelitian Hamdalah, A, (2011)

Tabel 4. Perbedaan efektifitas pengetahuan dan sikap responden pada kelompok film animasi dan kelompok film cerita

\begin{tabular}{lcccc}
\hline \multirow{3}{*}{ Pengetahuan } & Metode & N & Mean Rank & P \\
\cline { 2 - 5 } & Animasi & 31 & 39,24 & .002 \\
Sikap & Cerita & 32 & 24,98 & \\
& Animasi & 31 & 33,45 & .505 \\
& Cerita & 32 & 30,26 & \\
\hline
\end{tabular}

Berdasarkan hasil pada Tabel 4 diatas dapat disimpulkan bahwa kelompok film animasi lebih besar dari pada film cerita. Hal ini menandakan bahwa film animasi lebih efektif dalam meningkatkan pengetahuan dan sikap responden tentang menjaga kesehatan gigi seperti menggosok gigi pagi setelah sarapan dan menjelang tidur malam

\section{PEMBAHASAN}

Sebelum diberikan penyuluhan kesehatan dengan mengunakan metode pemutaran film animasi dan film cerita pada siswa siswi kelas 3A dan 3B responden telah memiliki kesamaan karakteristik yaitu secara keseluruhan usia siswa kelas 3A dan 3B di Sekolah Dasar Negeri 03 Kepanjen Kab. Malang berusia 8 sampai 10 tahun. Dari hasil penelitian diketahui sebagian besar responden berusia 9 tahun. Sesuai dengan yang disampaikan oleh Sumantri (2006), bahwa pada usia ini dikategorikan dalam masa kelas tinggi sekolah dasar. Pada masa ini anak memiliki kemampuan mengingat (memori) dan bahasa yang berkembang sangat cepat. Pada masa kelas tinggi anak gemar meniru, telah mampu mulai hidup mandiri, sudah memiliki rasa tanggung jawab pribadi, cara pandang terhadap dunia luar tidak hanya dipandang dari diri sendiri tetapi juga dilihat dari diri orang lain, dan sudah menunjukkan sikap yang kritis dan rasional. Sedangkan pada kategori jenis kelamin pada kedua kelompok tersebut adalah didominasi perempuan, dan pendidikan terakhir orang tua siswa adalah SMA atau SLTA.

Berdasarkan hal tersebut maka penelitian ini menggunakan media komunikasi sebagai salah satu wujud dari upaya kesehatan sekolah. Usaha pelayanan kesehatan gigi di sekolah merupakan salah satu pendekatan edukatif yang bertujuan meningkatkan kemampuan dan peran anak sekolah dalam memelihara kesehatan gigi. Karena kesehatan gigi dan mulut dapat mempengaruhi keadaan kesehatan tubuh secara menyeluruh dan kesehatan gigi dan mulut merupakan bagian yang integral dari kesehatan tubuh (Malik, 2008)

Pada hasil penelitian menunjukan hasil bahwa sebagian besar kelompok film animasi memiliki tingkat pengetahuan yang baik, dan cenderung mengalami peningkatan pengetahuan setelah dilakukan intervensi. Tingkat pengetahuan pada kelompok film cerita didapatkan hasil bahwa sebagian besar kelompok film cerita memiliki tingkat pengetahuan yang cukup, dan cenderung mengalami peningkatan pengetahuan setelah dilakukan intervensi. Hasil penelitian menunjukan bahwa pada kelompok film animasi dan film cerita didapatkan hasil analisis menggunakan uji Mann Whitney Testyaitu terdapat perbedaan pengetahuan yang signifikan antara film animasi dan film cerita dalam menjaga kesehatan gigi.

Hal ini sesuai dengan penelitian sebelumnya milik Widhyningrum (2012) penelitian tersebut menjelaskan bahwa kelompok responden yang diberikan intervensi berupa pemutaran film animasi 
dapat menunjukan ada peningkatan yang signifikan terhadap pengetahuan.Hal ini juga sejalan dengan penelitian sebelumnya milik Aida V (2007) menjelaskan dalam penelitiannya audio visual film cerita terhadap peningkatan pengetahahuan berpengaruh signifikan dalam peningkatan pengetahuan. Sebagian besar pengetahuan merupakan ranah yang sangat penting untuk membentuk tindakan seseorang. Perilaku yang didasari oleh pengetahuan akan lebih langgeng jika dibandingkan dengan perilaku tanpa didasari pengetahuan (Maulana, 2009). Pengetahuan merupakan hasil "tahu" dan ini terjadi setelah orang mengadakan penginderaan terhadap suatu objek tertentu. Penginderaan terhadap obyek terjadi melalui panca indra manusia yakni penglihatan, pendengaran, penciuman, rasa dan raba dengan tersendiri Pengetahuan sebagian besar diperoleh dari indera penglihatan sebesar 30\% dan indera pendengaran sebesar $10 \%$.Pada waktu penginderaan sampai menghasilkan pengetahuan tersebut sangat dipengaruhi oleh intensitas perhatian presepsi terhadap obyek. Sebagian besar pengetahuan manusia di peroleh melalui mata dan telinga. (Notoatmodjo, 2012).

Berdasarkan hasil analisisi menunjukan bahwa terdapat peningkatan pada ranah sikap siswa setelah diberikan intervensi beruapa pemutaran film animasi dan film cerita tentang kesehatan gigi, tetapi tidak terdapat perbedaan sikapyang signifikan antara film animasi dan film dalam menjaga kesehatan gigi. Hal ini sesuai dengan penelitian sebelumnya milik Putra. P.A, ( 2013) Pengaruh Tayangan Film Kartun "Crayon Shinchan" Terhadap Perilaku Anak Dengan Orang Tua Pada Sekolah Dasar Yayasan Wisma Semen Gresikdalam penelitiannya pengaruh menonton tayangan film animasi Crayon Shincan terhadap peningktan sikap anak tidak terdapat pengaruh yang signifikan. Sama Halnya pada penelitian milik Saputra .F .A (2016). Media film cerita terhadap peningkatan sikap dalam penyuluhan perikanan budidaya tidak terdapat perbedaan yang signifikan terhadap peningkatan sikap siswa.Adanya media berupa film animasi maupun film cerita tentang menjaga kesehatan gigi merupakan objek penyampaian pesan yang belum cukup untuk meningkatkan stimulus pada responden sehingga pembentukan sikap tentang menjaga kesehatan gigi belum dapat terwujud.

Sikap adalah juga respon tertutup seseorang terhadap stimulus atau objek tertentu, yang sudah melibatkan faktor pendapat dan emosi yang bersangkutan, senang-tidak senang, setuju-tidak setuju, baik-tidak baik dan sebagainya (Notoatmodjo, 2012). Sedangkan menurut teori Green, bahwa faktor perilaku ditentukan oleh 3 faktor.Pertama, faktor predisposisi (pre disposing factor), yaitu faktor yang mempermudah atau mempredisposisi terjadinya perilaku seseorang. Kedua, faktor pemungkin (enabling factor), yaitu faktor yang memungkinkan atau yang menfasilitasi perilaku atau tindakan. Ketiga, faktor penguat (reinforcing factor), yaitu faktor yang mendorong atau memperkuat terjadinya perilaku

Efektifitas media dapat dilihat dari nilai rerata atau mean rankpost-test. Penentuan efektifitas media dengan menggunakan nilai rata - rata post-test tersebut dirujuk dari penelitian (Hamdalah, A, 2011) mengenai perbedaan efektifitas media. Hasil penelitian menunjukkan bahwa film animasi dapat dikatakan lebih efektif dalam meningkatkan pengetahuan dan sikap. Walaupun sebenarnya film cerita juga dapat meningkatkan pengetahuan dan sikap responden, namun peningkatan pada film cerita yang digunakan didalam penelitian ini dinilai kurang efektif karena memiliki nilai mean yang lebih rendah dari pada nilai mean film animasi.Hal ini dilihat dari hasil rerata dari kedua kelompok maka dapat disimpulkan bahwa efektifitas media dengan metode pemutaran film animasi lebih diminati oleh responden dari pada media film cerita. Hal ini sesuai dengan hasil penelitian sebelumya milik Widhyaningrum, (2012) bahwa didalam penelitiannya yang 
berjudul keefektifan penyuluhan kesehatan menggunakan media film animasi dalam meningkatkan pengetahuan siswa tentang penyakit demam berdarah pada siswa SD Kalisapu media film animasi efektif dalam meningkatkan pengetahuan atau penyampaian informasi pada siswa-siswi Sekolah Dasar. Semakin banyak pengetahuan yang terserap oleh responden maka semakin besar pula peluang seseorang untuk melakukan dan mempertahankan suatu perilaku kesehatan. (Notoatmodjo, 2012). Film animasi memiliki kelebihan yang berbedadalam menarik perhatian siswa, warna ataupun gambar yang menarik, animasi juga mampu mempermudah responden merekam suatu proses kejadian dan juga memiliki nilai hiburan tersendiri bagi pemirsanya (Effendi, 2009).

Media audio visualsesuai untuk anak usia sekolah karena dapat mengembangkan imajinasi dan aktivitas belajar anak dalam suasana menyenangkan sehingga dapat merangsang minat belajar anak karena ditampilkan dalam bentuk animasi yang menarik dan mudah dipahami. Sekolah yang mayoritas respondennya berusia 8 sampai 10 tahun berada dalam tahap operasional konkrit yang artinya aktivitas mental yang difokuskan pada objek - objek peristiwa nyata atau kongrit (Sumantri \& Nana Syaodih 2006). Padatahap usia sekolah dasar anak mulai memperoleh dasar ilmu pengetahuan dan pengalaman di sekolah dan menjalin hubungan yang luas dengan orang lain seperti guru, teman sekelas dan sekitar lingkungan sekolah. Pada usia kelas tinggi anak sudah memiliki cara berfikir yang sangat realistis dan rasa ingin tauyang besar dan ingin belajar hal-hal yang baru ( Sumantri \& Nana Syaodih 2006).

Berdasarkan penelitian didapatkan film animasi mampu memberikan peningkatan pengetahuan lebih tinggi kepada responden yang berusia 9 tahun dalam meningkatkan pengetahuan dan sikap menjaga kesehatan gigi sehingga kedepannya dapat dimanfatkan sebagai media promosi. karena media massa memiliki pengaruh yang sangat besar dalam pembentukan pengetahuan, sikap seseorang (Notoatmodjo, 2009)

\section{SIMPULAN}

Berdasarkan hasil penelitian tentang perbedaan efektifitas pendidikan kesehatan menjaga kesehatan gigi metode film animasi dan film cerita terhadap peningkatan pengetahuan dan sikap siswa Sekolah Dasar Negeri 03 Kepanjen Kab. Malang dapat disimpulkan bahwa terdapat perbedaan antara film animaisi dan film cerita terhadap peningkatan pengetahuan. Film animasi lebih efektif dari pada film cerita tentang menjaga kesehatan gigi dalam meningkatkan pengetahuan dan sikap responden yang berusia 8 sampai10 tahun.

\section{DAFTAR PUSTAKA}

Aida, V. 2007. PengaruhDesain Pesan Vidio Instruksional Terhadap Peningkatan Pengetahuan Petani Tentang Pupuk Agrodyke. Skripsi. FEMA IPB

Azwar S. 2001. Sikap Manusia Teori dan Pengukuranya. Jakarta: Pustaka Pelajar.

Dinkes Prov. Jatim. 2013. Profil Kesehatan Provinsi Jawa Timur Tahun 2013.

Dony, K. 2011. Jenis Jenis Film Dokumenter.

Dorothy. Y.B, Merie T. (2008). Dasar Dasar Riset Keperawatan. EGC :Jakarta.

Effendi, F \& Makhfudli. 2009. Keperawatan Kesehatan Komunitas : Teori dan Praktek Dalam Keperwatan. Jakarta: Salemba medika.

Effendy,2013. Ilmu Komunikasi Teori dan Praktek. Bandung: PT Remaja Rosdakarya

Fankari. 2004. Pengaruh Penyuluhan Dengan metode Stimulasi dan Demonstrasi Terhadap Perubahan Perilaku Menjaga Kesehatan Gigi Dan Mulut Anak Sekolah Dasar. Karya Tulis Ilmiah DIV. Perawat Pendidik UGM 
Green. 2011. Lawrence W. Health Promotion Planning An Educational and Enviromental Approach. Mayfield Publishing Company. London : Mountain View - Toronto

Hamdalah, A. 2011. Perbedaan Efektifitas Metode Cerama Dengan Media Cerita Bergambar Dan Ceramah Dengan Media Permaian Ular Tangga Dalam Meningkatkan Pengetahuan, Sikap dan Niat Praktik Kesehatan Gigi Dan Mulut. Skripsi.Universitas Jember.

Kemenkes RI. Profil Kesehatan Indonesis tahun 2007. Jakarta : Kemenkes RI: 2008.

Malik. 2008. Hasil Penelitian Fakultas Kedokteran Gigi. Jurnal. Universitas Indonesia.

Mubarak, Wahit Iqbal, dkk. 2007. Promosi Kesehatan Sebuah Pengantar Proses Belajar Mangajar dalam Pendidikan. Yogyakarta: Graha Ilmu.

Notoatmodjo, S. 2007. Promosi Kesehatan dan Ilmu Perilaku. Jakarta : Rineka Cipta.

Notoatmodjo. 2010. Metodelogi Penelitian Kesehatan. Jakarta : PT. Rineka Cipta.

Notoatmodjo. 2012. Promosi kesehatan dan perilaku kesehatan. Jakarta : Rineka Cipta

Nursalam. 2010. Konsep Dan Penerapan Metedologi Penelitian Ilmu keperawatan. Jakarta: Salemba medika

Pratiwi, D. 2007. Gigi Sehat. Jakarta: PT. Kompas Media Nusantara

Profil kesehatan Provinsi jawa timur tahun 2013. Jawa timur. Dinkes Jatim: 2014

Putera. P. A. 2013. Pengaruh Tayangan Film Kartun "Crayon Shinchan" Terhadap Perilaku Anak Dengan Orang Tua Pada Sekolah Dasar Yayasan Wisma Semen Gresik. Jurnal. Universitas Airlangga. Surabaya.

Riset Kesehatan Dasar(Riskesdas). (2013). Badan Penelitian dan Pengembangan
Kesehatan Kementerian RI tahun 2013.

Sandya, I.W. 2018. Perbedaan Efektivitas Film Animasi Dan Film Cerita Terhadap Peningkatan Pengetahuan, Keyakinan, Sikap Dan Niat Anak Tentang Menjaga Kesehatan Gigi Di Sekolah Dasar Negeri 03 Kepanjen Kab. Malang. Skripsi. Universitas Airlangga: Surabaya

Saputra, F.A. 2016. Efektifitas Video Terhadap Peningkatan Pengetahuan

Dan Perubahan Sikap Dalam Penyuluhan Perikanan Budidaya. Skripsi. Fakultas Ekologi Manusia Institut Pertanian Bogor.

Sugiyono. 2007. Metode penelitian Kuantitatif, kualitatif, dan $R \& D$. Bandung:Alfabeta.

Sugiyono. 2013. Metode Penelitian Pendidikan Pendekatan Kuantitatif, Kualitatif, dan R\&D. Bandung: Alfabeta.

Sumantri, M \&permana, J (2006), Perkembangan Peserta Didik, Bandung: Universitas Terbuka.

Widhyaningrum, M. 2012. Keefektifan Penyuluhan Kesehatan Menggunakan Media Film Animasi Dalam Meningkatkan Pengetahuan Siswa Tentang Penyakit Demam Berdarah Pada Siswsa SD Kalisapu 01 dan 02: Under Graduates thesis, Universitas Negeri Semarang

Wong, L. Donna. 2009. Buku Ajar Keperawatan pediatrik Vol 1. Edisi 6. Jakarta : ECG

Worotitjan, I., Mintjelungan, C. N., \& Gunawan, P. 2013. Pengalaman Karies Gigi Serta Pola Makan dan Minum Pada Anak Sekolah Dasar Di Desa Kiawa Kecamatan Kawangkoan Utara. 